UDC $81-11$

DOI https://doi.org/10.32837/2312-3192-2018-11-119-126

\title{
SPECIFIC ASPECT OF VERBAL INFLUENCE IN MISSIONARY SERMON (ON MATERIAL RUSSIAN LANGUAGE SERMONS OF PASTOR S. ADELADGA AND PASTOR V. MUNTYAN)
}

\author{
Olena Klymentova ${ }^{1}$
}

\begin{abstract}
The article is devoted to the verbal specification of the modern missionary sermon of the Ukrainian proselyte discourse, which is based on media activity of Pastor S. Adeladga and Pastor V. Muntyan. Pastor's communicative strategies and tactics of the verbal influence which are realized in the system of pragmatic presuppositions and frameworks: interactional frameworks, contextual frameworks and participation frameworks, which are analyzed. The separate group in research materials constitutes certain forms of the verbal activity which are produced by emotional trust. The author distinguished this perlocutive effect as a latent form of aggression in the missionary sermon. The results of research showed that the phenomenon of emotional trust allows the introduction of destructive experience in the recipient's consciousness and adds more drama to real individual problems. As it was stated, the main mechanisms and units of communicative influence in the missionary sermons are correlated with the verbal manipulation, Neuro-Linguistic Programming and the hypnotic techniques' components.

The peculiarity of verbal behavior of the leader of religious group and strategies of leader's self-presentation in the status-role communication are also analyzed in the article. The article represents different viewpoints of scholars to studying such a multidimensional phenomenon of the examination of religious text which is relevant to verbal manipulation. The author suggests to use the elements of interactional sociolinguistic method as an analytical instrument for linguistic examination of the proselyte sermons as well. The perspective of scientific qualification of the pathogenic verbal activity as the form of aggression of religious text is being analyzed in the article.
\end{abstract}

\section{Keywords}

Missionary sermon, proselyte discourse, verbal behavior, status-role communication, trust, verbal influence, linguistic expertise, manipulation, suggestion.

1. Introduction. Communicative manipulations have been in the focus of psychologists and other researchers for many times. It is a complex phenomenon that may be dealt with in ethical, semantic, pragmatic, psychological, social and cultural terms. But the linguistic profiles of the whole manipulative communication process are rather hard to identify. There are different views of researchers about the main linguistic markers of manipulation as well as the notions of manipulation and its characteristics. Manipulation is manifested in the verbal explications and implications which are correlated with lie, deception, aggression, conflict, and invective, fiction, illusion etc. But it should be notices that the features of linguistic influence are distinguished in the different discourses and suggestive influence in particular (Klymentova ${ }^{2}$, Kovalevska ${ }^{3}$, Kompantseva $^{4}$, Kutuza $^{5}$, Slukhaj ${ }^{6}$, Sedov').

${ }^{1}$ Prof. Dr. of Philology O. Klymentova, Taras Shevchenko National University of Kyiv, Institute of philology, Taras Shevchenko avenue, 14, 01601- Kyiv, Ukraine, Email: klymentovaov@ukr.net

${ }^{2}$ Klymentova 2012; 2012a:

${ }^{3}$ Kovalevska 2016, 227:

${ }^{4}$ Kompantseva 2018:

${ }^{5}$ Kutuza, 2016. 178 - 189:

${ }^{6}$ Slukhaj 2012:

${ }^{7}$ Sedov 2011:

${ }^{8}$ Gumperz 2003:

${ }^{9}$ Goffman 1974: 1982:

${ }^{10}$ Denzin, 2002
2. The object of our research is proselyte communicative suggestion. The subject of our article is linguistic markers of suggestion in the missionary sermon. The main purpose of this paper is to characterize features and linguistic markers of the proselyte communicative manipulation. The tasks are the following: to compare the communication of trust in Orthodox sermon discourse and the communication of trust in status-role communication of proselyte discourse; to describe the peculiarities of missionary sermon in proselyte discourse and peculiarities of verbal behavior of leader of religious group; to systemize approaches to the analysis of linguistic markers of communicative manipulation in the missionary sermon.

3. Methodology. In this research the author used methodology of interactional sociolinguistic (Gumperz ${ }^{8}$, Goffman ${ }^{9}$, Denzin ${ }^{10}$ ), which is bases on the theory situational inference in anthropological perspective: motivation nature of language in its connection with cultural and social factors and which is bases on the theory of frame's interaction. The methodology is based on the complex of methods of analyses of discourse with the aim of finding out and explanation of situational meanings. In the focus of work we can find identification of discourse strategies. The great attention is given to the approach of Erving Goffman, who took into consideration the type of interaction (face to face). While the process of work with certain contexts a system of frames, which give the oppor- 
tunity to find out the mechanisms of comprehension and mutual construction of participants of interactional meanings was used. Of cause, we mean preferable interactional interpretations. In Goffman's approach the mechanisms of constructing certain roles and their transformation while the processes of interaction are in focus. Also in accordance with these approaches the author took into consideration general knowledge of communicators (presuppositions) of 3 kinds: interpersonal, conventional-communicative and situational. They shape certain frames of interactional, contextual and participation ones correspondently.

Frame of interaction Goffman represents as the matrix of some events and summit of roles. This model of interaction is perceived, but not created by preferable space of the context. Interactional frameworks are close to the idea of "type of activity" or speech activity. Contextual frame is correlated with the frame of interpreting.

Goffman's interaction is constructed by frames. The behavior of each communicator is associated with the certain scenario and dynamic of role is regulated by expectance of behavior possible to each status.

For this research a certain repeated types of speech contacts which are characterized by thematic coherence, prosodic specification and stylistic formal markers and influencial function with the aim of selecting data relevant to investigated problem have been selected and presuppositions of subject were described. The subject of speech activity is Pastor, whose speech strategies and tactics are analyzed.

4. Results and Discussion. All religious genres are corresponded to the different emotional conditions of a person and a sermon in particular.

Stephen T. Asma, a philosophy professor at Columbia College in Chicago, writes in his new book "Why We Need Religion" due out from Oxford: "People think of religion as a system of beliefs but it is fundamentally an emotional management system, one that science and any other kind of "cultural technology" cannot offer" ${ }^{11}$. He stresses that "the brain has different operating systems and the rational part it is fairly new. Religion speaks to the oldest part of the brain and it has a therapeutic mission to manage our emotional life"12.

A theological sermon is pragmatic text. The sermon as a genre of biblical rhetoric is characterized by the use of didactic reasoning and ethical-speech principles, various figurative and expressive means (allegories, metaphors, and comparisons), syntactic figures (anaphora, hyperbole) and rhetorical questions, complaints as well. But the spiritual eloquence of theological sermon is used for giving of sacral

\footnotetext{
${ }^{11}$ Why an agnostic philosophy...

${ }^{12}$ The same.

${ }^{13}$ Rotter, 1990, 154

${ }^{14}$ Beckford, 2002, 8
}

knowledge. This is the sacral ritual communication of trust. A theological sermon is corresponded with trust. This is the emotional condition in which person does not defend from information.

The missionary sermon is always opposed to the Orthodox sermon as different types of communication which are correlated with trust. The primary function of trust in Orthodox approach is the translation of information with sacral status from one generation to other generation orally. This type of trust has become an integral part of our moral values, culture, mental and religious life. The meaning of trust contains much more issues than emotional condition of a person. It has already been mentioned that the trust differs from other forms of respect because it was true evolution experience.

Julian B. Rotter wrote in his work "Trust and Gullibility" that "Some psychologists, like Erik Erikson, see trust as a basic belief in the goodness of others and in the benign nature of the world. They believe that the capacity for trust is largely determined early in life by the mother's care of the infant in the first few weeks of life. I think that the inclination to trust or distrust is probably learned over a longer period of time, and that is results from a person's cumulative experiences. In our research we have defined trust as a 'generalized expectancy' that the word, the promise, the verbal or written statement of another individual or group can be relied upon"13.

The separate group in research materials constitutes certain forms of the verbal activities which are produced by emotional trust in the proselyte discourse. The author distinguished this perlocutive effect as the latent form of aggression in the Ukrainian reality with its Orthodox dominant.

But there are similar views of scholars about the social activities and influencial practices of different religious organizations. For example, James A. Beckford writes that religious diversity is a part of pluralistic ideology in US in practically and, as a social phenomenon, religious groups make serious contribution into religious culture and in the context of culture in general. From rational and scientific point of view the research of activities of these groups is necessary to be done not to forbid but for relationship among traditional and proselyte confessions, and for social stabilizing.

James A. Beckford suggests using of the term "competition" and writes: "Indeed, the term "competition" is appropriate only because religious diversity occurs within a moral-cum-legal framework regulating relations between religious groups. In the absence of such a framework, competition would be less likely than "conflict" or "mutual indifference ${ }^{14}$. This point of view is corresponded to the high level of tolerance to proselyte confessions. Maybe, it will be topical for Ukrainian reality as the main metaperspective in future. But today it is correlated with the different problems of Ukrainian society weakly and it promotes 
social destabilization. In this aspects the proselyte communicative discourse could be considered as a favorable object for the process of language research.

According to our position, the pragmatic phenomenon of emotional trust, which is practiced in proselyte discourse, allows introducing of destructive experience in the recipient's consciousness.

The fact is that, on the contrary, the emotional trust is pragmatic aim in the proselyte discourse, which is relevant to the latent form of impersonal pathogenic influence. Most scholars have regarded it as an element of manipulative communication. With their proposals the leaders of religious groups, and $\mathrm{V}$. Muntyan the same, position themselves in opposition to those semantic references which are represented in Orthodox sacral discourse. Usually the audience believes that the information that is presented in sermon is true and undeniable. The missionary sermon is used the higher rating of social respect to church and parasitized on the sermon's tradition.

The study of different levels of organization of missionary sermon, it's prosodic, lexical, and semantic and other aspects, markers of Pastor's linguistic behavior as well, can give us a considerable insight into the nature of Orthodox sermon and missionary sermon identity. As to the missionary sermon, it includes new ways of solution of old problems. As usual Pastor describes some episodes of sacral text and suggests its interpretation. While his speech he uses the certain communicative strategies, tactics and means of verbal influence. They are realized in the system of pragmatic presuppositions and frameworks which help to construct a new reality, beliefs and values. According to the methodology of Interactional Sociolinguistics, we have regarded them as interactional frameworks, contextual frameworks and participation frameworks ${ }^{15}$. The interactional frameworks are correlated with the genre nature of communication and the different forms of personal activities, kinds of actual situations (for examples: loss of work, absence of money, hard illness). There are different problems that people were unable to decide themselves for a long time.

The contextual frameworks represent the interpretation versions, whilst participation frameworks include the models of behavior ${ }^{16}$. As usual Pastor has some interesting ideas as to what way people can make a lot of progress.

Sunday Adeladga, for example, has defined the debts as the shortest way to the wealth and prosperity, a way to success. S.Adeladga has stated in his work with the name "Success in everywhere", that the

\footnotetext{
${ }^{15}$ Kravchenko, 2017, 152 - 155

${ }^{16}$ The same

${ }^{17}$ Adeladga, 2002, 48

${ }^{18}$ Adeladga, 2002, 40

${ }^{19}$ Adeladga 2002, 40
}

debts are not a problem; they are stimulating the money traffic. The more debts you have the more changes happen in the personal finances. The idea that poverty and debs are terrible, Pastor reinterprets into the new logical connection: poverty - debs - trust in God's word-millions of money - happiness which is based on the positive emotive correlation. Pastor stresses: «Поинтересуйтесь у любого миллионера, что толкнуло его поверить слову Божьему и стать успешным человеком? Он ответит вам: «Долги». $B$ «долине плача» он открыл источник, который стал сказкой современного бизнеса».

("Ask any millionaire, what pushed him to believe a word of God and become a successful person? $\mathrm{He}$ will answer you: "My depts." In 'Valley of crying' he discovered the source which has become a fairy-tale of modern business") ${ }^{17}$.

Pastor uses such kind of linguistic influence as persuasion tactics. The participation frameworks are based on the positive examples in the specified contexts which are proposed the audience: «Возможно, на сегодняшний день вы очень нуждаетесь, у вас ничего нет. Начните служить людям, и уверяю вас на основании слова Божьего: вы поднимитесь из бедности. Божьи законы начнут работать в вашу пользу, и вы получите вознаграждение. Сейте любовь и вы пожнете богатый урожай. Любовь к Богу и работа для Царства - вот ключ к величию в жизни». ("Maybe today you are desperately in need, you have nothing at all. Let us start to serve people and be sure that on the ground of God's will you will relieve from. The God's lows will start working for your benefits and you will be granted reward. Sow love and you will gather the rich crop. Your love to God and your work for Kingdom - all these ideas are the key to the glory in life" $)^{18}$.

He prefers to generalize narratives, uses many words with meliorative semantic, paralogical sentences etc. But such kind of linguistic profile corresponds with the avoidance.

Pastor suggests such frames of social reflections: «начните мечтать, начните фантазировать и просить у Бога...»; «Просите у Бога...» ("Let us start dreaming on indulge in fancies and asking God for", "Ask God for") ${ }^{19}$. He uses linguistic markers of intimacy, reading of intentions, empathy-oriented references to audience and, of course, and the authority of sacral text.

Pastor's argumentation is based on using an analogical knowledge. S. Adeladga considers, for example: «Выдаюшимися не рождаются и богатыми не рождаются, ими становятся вследствие пережитых серьезных проблем и неприятностей, которые людям удалось преодолеть». ("You are not born an outstanding person and are not born a rich one. You are becoming those ones as a result of experiencing serious problems and misfortunes which 
people managed to overcome" $)^{20}$. This text is based on the psalm (Ps. 83: 6-8).

Sacral text can function as prototypical source which is represented by this specified context. “Долина плача" (Valley of crying) is the main metaphor for generalization of all kinds of problems. To support this fact, there are numerous isomorphic designs in missionary sermon of S. Adeladga.

Sometimes his owner sacral experience is proposed as analogical knowledge: "Мне в свое время Бог сказал: "Оставь работу журналиста и посвяти себя пасторскому служению». Я был в недоумении: «Господь, но что же я буду кушать? Как буду жить?» Бог ответил: «Трудящиийся достоин пропитания. Трудись в своем призвании, и тогда деньги сами придут к тебе». - На сегодняшний день Он обеспечивает меня и мою семью. Бог снова и снова оказался верен Своим словам. Зарплата - это всего лишь следствие работьл. Выполняйте свое дело добросовестно, и Бог даст вам возможность стать вам богатымм. ("I was told my God one day: "Leave your work as a journalist and devote yourself to pastor's service". I was astonished so much: "Oh, my God! What I am going to eat? How I am going to live?" The God answered me: "Those who are working deserve to be fed. Do work in your vocation and money will come to you immediately". - Today He maintenances me and my family. The God again and again occurred to be devoted to his words. Your salary is just the result of your work. Do you task persistently and the God will give you the chance to be rich") ${ }^{21}$.

The leader of religious organization positioned himself as a mediator between two realities - God's sphere and world of people.

It is a well-known fact that the members of religious groups are united around the person of leader. According to this view, the communicative behavior of Pastor has a separate sense. The leader of religious organization focuses on himself as a successful person and also describes himself as means of expressing God's will. The pastor's person is positioned as an example of coping him.

The Pastor's main communicative strategy is a strategy of associating with the sacral sphere, but the main communicative tactic is the emotional influence. Presuppositions are important instrument of realization of pastor's communicative strategies and tactics. Presuppositions, as background knowledge, determine the principles of verbal representations of reality in proselyte discourse. The importance of presuppositions is in the fact that they can be the speaker's illocutionary force toward an implicit content that must be recovered through inference.

\footnotetext{
${ }^{20}$ Adeladga 2002, 46

${ }^{21}$ Adeladga, 2002, 61

${ }^{22}$ Here and father all quotations are from: vo.org.ua/tv/archive
}

That is why presuppositions are markers of implicit instructions of the leader. Presuppositions and contextual frameworks can introduce subjective codes into the recipient's objective reality. The contextual frameworks have a higher cognitive load and correspond to the linguistic intelligence of the leader. This is one of the key characteristics of the leadership communicative style.

All communications of the group members may be channeled through the leader, making him the source of all the inside information, what is more, all members of the group can be given the information directly, thus reducing the leader's influence. The missionary sermon is the comfortable means for both kinds of the leader's influence.

The research proves that V. Muntyan leadership style is based on using the similar communicative strategies and tactics. It was found out that V. Muntyan often uses assertion. He constants, describes, explains reality, which is known only to him. The peculiarity of leader's self-presentation of V. Muntyan in the religious status-role communication is the frequentation of reference to his sacral experience.

His speech includes markers of truth-teller witness, who reproduces the sacral information or describes existential visions: "Бог хочет, чтобы...», «Дьявол сегодня в шоке», «Бесы сегодня в шоке», «Демоны в ужсасе»; "И тогда мне конкретно Бог проговорил, когда пройдет 14 лет, тогда посетит Дух Святой»; "Я стал на колени и сказал: "Дух Святой, прийди! Стоял на коленях и ждал...И в один момент Он зашел. Я внутри сказал: "Пожалуйста, подойди, коснись». И представьте, Он подошел... Коснулся меня...» ("The God wants..."; "Devil is in shock today"; "Demons are in shock today"; "Demons are in horror"; "And just in that moment the God said to me, when you are 14 the Saint Spirit will come to you". I kneeled and told him: "Saint Spirit, please, come to me! I was kneeling and waiting ...And on the spur of the moment He came. I told myself: "Please, come up to me and touch me". You know, He came... Touched me..."22.

In tactics of self-presentation he pays a special attention to himself as an unusual person who has mission of mediator. That's why pastor repeats many times: "Я чувствую...Я ощцщаю" ("I feel...I sense..."). He also describes the invisible processes: "Дух Святой пришел. Дух Святой начал двигаться. Он сегодня проявится. Я знаю наперед, потому что уже тысячи исиелились». ("Saint Spirit has come. Saint Spirit started his movement. He will be visible today. I know it in advance because thousands were healed").

Sometimes pastor uses the hypnotic infusions directly. For example, this way he describes the moment of the unction: "Человек стоит и чувствует, как тепло проходит по его телу. Именно в том 
месте, где болит. Слушайте!» ("A person is standing and feeling as warmth is spreading all my body, and just spotting that place which is hurting so much. Do listen!") or he proposes the real influence texts: «Помазание - мой иммунитет. Мой разум помазан Святым Духом. Я процветающий человек! Скажи: «Я процветающий человек!». ("Unction is my immunity. My mind is unctioned by Saint Spirit. I am a prosperous man! Do say: "I am a prosperous man!"

V. Muntyan stresses that he makes good. This is one example of how this might be done: prayer's phrase «Я благодарю Господа» (I am thankful to God!") turns into: «Я благо дарю!» ("I present you goodness!").

It has new sense and focuses on pastor's person. Pastor repeats it many times in his reports and he uses manipulative function of language systematically in the tactics of self-presentation.

He also describes emotions of people which are reverted to him: «Люди в благодарность приходят, люди хотят отблагодарить меня, люди хотят быть частью истины. Люди счастливы. Они знают...». ("People are coming with gratitude, people have desire to be thankful, people are eager to become a part of thruth. People are happy. They know..."). V. Muntyan uses certain words with positive emotions in a specific way. These emotions also have some function of latent social characteristics of Pastor.

But he pays a special attention to linguistic activity which is produced by emotional trust. The author distinguished this perlocutive effect as the latent form of aggression because Pastor disturbs the ethic norms and ignores civilized approaches.

The nature of correlation religious beliefs with health of person was studied many times. From scientific point of view there is relation between religious beliefs and mental health mainly. The American scholars confirm that "people who believed they had a good relationship with God had better mental health outcomes than those who thought they had a poor relationship with God" 23 . This is a positive aspect of religious coping. But the correlation religious beliefs with the organic disorders are not true. That is why refuse from the medical help is considered to be destructive and unhumanistic.

But Pastor V. Muntyan distances from these ethic norms in his media prayers for good health. The prayer for good health is a real media brand of V. Muntyan. In edition Pastor distances from Orthodox point that illness is caused by individual sins or breaches of moral and ethical rules. His main theoretical point of sermon is to argue idea that God is love. V. Muntyan uses the strategy of emotional influence. Pastor's definition of the concept of 'health' is connected with

${ }^{23}$ Flannelly, 2017, 305 the results of God's unction. The analogical knowledge of this metaphor is sprouted into biblical story about Sarra and Avraam.

That is why rational explicators of concept (tablets, diagnose, doctor, consultation, treatment, surgeon, a model of life, nutrition and other) have certain connotation with emotional negativism. According to Pastor's point, sick people need to find the communicative contact with God. Pastor helps to organize this contact.

V. Muntyan's prayer in good health contains many components which correspond to phenomenon of the linguistic programming of personality and hypnotic technique. For example, Pastor pays a special attention to the prosodic mechanisms of communicative influence. He uses different intonation patterns which are systematically based on the suggestion function. He uses cry, whisper, intimacy, irony, order, silence etc. This intonation palette is correlated with the activities of right hemisphere of brain and it courses reduction of ration thinking.

Pastor also uses built-in commands (as verbalizators of rapport) for activation of different information channels: "Посмотрите... (vision), что происходит... Слушайте(audio)... Читай (vision) про страдания Христа, ть должен прочитать (vision) свою историю, возможно, даже увидев (vision) ... Оденьте (kinesthetic) эту мантию..." / "Look (visual), what is going on... Do listen (audio)... Read (vision) about Christ's sufferings, you must read (vision) your story, may be, even if you see (vision)... Put on (kinesthetic) this gown".

Healso uses modal operators: «Когда тьл думаешь об Исусе, он должсен стать твоим личным спасителем»; «Bbl долюнны понимать...»; «история с Исусом должнна стать личной историей»; "Жизнь долюнна переплестись...» etc. / "When you think about Christ, He must become your own Saviour"; "You must understand..."; "A history with Christ must be your own story"; "Life must intertwine";

- nominalizations: помазание Святьм Духом, знакомство с Духом Святым, проклятие туберкулеза, проклятие астмы; / "unction of Saint Spirit, acquaintance with Saint Spirit, damnation by tuberculosis, damnation by astma;

- causative complex: "Причина - она в крови Исуса Христа. Кровь - это основание, именно поэтому... Именно из-за крови...»; «Потому что Исус Христос пролил свою кровь, поэтому сегодня он может прийти и к тебе»; / "The cause is in the blood of Jesus Christ. Blood is the basic that is why...Because of Blood..." "Jesus Christ poured his blood as a result he can come to you today".

- comparative constructions: «Исус-ходатай, $о н$ не прокурор. Скажи: «Ходатай». -Он ходатай, не прокурор»; «Христос - твой личный защиттник. Христос - твой личный целитель» etc. / "Jesus 
is your patron, but not a prosecutor". Christ is your own defender. Christ is your own healer".

Research results showed that phenomenon of emotional trust allows introducing of destructive experience in the recipient's consciousness and adds more drama to real individual problems. As it was stated, the main mechanisms and units of communicative influence in Muntyan's sermons are correlated with linguistic manipulation, Neuro-Linguistic Programming and the hypnotic techniques' components.

On the other hand, Muntyan's sermons are provided with the help of mass media. We cannot deny the fact that "whatever we know about our society, or indeed about the world in which we live, we know through the mass media"24.

G. Pocheptsov stresses that today modern media determine what is good and what is bad ${ }^{25}$. That is why the understanding of programming character of mission sermon is so important.

5. Conclusions. There are different viewpoints of scholars on studying such a multidimensional phenomenon of the lingo-cultural examination of religious text which corresponds to verbal manipulation. The functional religious text is a problematical object of linguistic expertise. It is known that the sacral texts are not an object of linguistic expertise. As for functional religious text it may be so. That is why thanks to the linguistic expertise hidden aspects which are correlated with the religious ex- tremism, aggression, conflicts and manipulation are being analyzed.

When we refer to linguistic manipulation we mainly associate it with lie, deception or fake. But when it concerns missionary sermon we speak more about verbal suggestion ${ }^{26}$. In addition, it is a kind of influence text which corresponds to the pathogenic psyche-ecological influence of the leader of religious group.

The verbal behavior of the leader of religious group is based on using of latent admissions which produce the emotional trust as perlocutive effect of influence. The author has distinguished this perlocutive effect as the latent form of aggression. Research results showed that the phenomenon of emotional trust allows the introducing of destructive experience in the recipient's consciousness and adds more drama to real individual problems. As it was stated, the main mechanisms and units of communicative influence in the missionary sermons are correlated with the verbal manipulation, Neuro-Linguistic Programming and the hypnotic techniques' components. The study of missionary sermon of its influence aspects can give considerable insight into the universal model of linguistic influence and suggestive influence in particular. In addition, understanding of influencial character of missionary sermon let to enlarge the list of expert tasks in the analysis of religious text.

\section{BIBLIOGRAPHY}

Аделаджа С. Успех во всем / Сандей Аделаджа. - К.: Светлая звезда, 2002. - 80 с.

Архив служений Владимира и Виктории Мунтян. Крусейд - Молитва за здоровье /25 февраля/ Владимир Мунтян [Электронный pecypc]: vo.org.ua/tv/archive; Берлин /Крусейд/ Молитва; Крусейд/Апостол/Молитва за здоровье. [Электронный ресурс]. - Режим доступа: http://vo.org.ua/tv/archive;

Климентова О.В. Вербальна сугестія сакральних текстів (на матеріалі українських молитов) / О.В. Климентова. - К.: ППНВ, 2012. $-371 \mathrm{c}$.

Климентова О.В. Вербальна сугестія та емоції (на матеріалі українських молитов) / О.В.Климентова. - К.: Каобон ЛТД, 2012. $-320 \mathrm{c}$.

Ковалевська Т.Ю. Нейролінгвістична ідентифікація метапрограмних стратегій особистості./ Т.Ю. Ковалевська / Записки 3 українського мовознавства. Вип. 23. Opera in linguistic ukrainiana, Fascicullum 23, Одеса: “ПоліПрінт”. С. $219-227$.

Компанцева Л.Ф. Лінгвістична експертиза соціальних мереж / Л.Ф. Компанцева. - К.: Аграр Медіа Груп, 2018. - 318 с.

Кравченко Н.К. Дискурс и дискурс-анализ: краткая энциклопедия / Н.К. Кравченко. - К.: ТОВ «НВП «Інтерсервіс», 2017. $-288 \mathrm{c}$.

Кутуза Н.В. Сугестія і маніпуляція: спільні і відмінні ознаки різновидів (видів) комунікативного впливу / Н.В. Кутуза // Записки з українського мовознавства. - 2016 . - № 24, т. 2. - С. 178-189.

Почепцов Г.Г. Информационные войны. Основы военно-коммуникативных исследований. Глава 2. Коммуникативное пространство [Электронный ресурс]. - Режим доступа: http://www. ligis. ru / library 2/049/18.html

Слухай Н.В. Суггестия и коммуникация: лингвистическое программирование поведения человека / Н.В. Слухай. - К.: ИПЦ «Киевский университет», 2012. - 319 с.

Beckford J. A. (2002) Bringing ideology Back in / J. A. Beckford // Research in the Social Scientific Study of Religion, V. 12., p. 8., edited by Moberg David O., Piedmont Ralf L, Brill, Leiden, Boston, Köln, 2002.

Van Dijk T. A. (1996) Discourse, power and access /T.A. van Dijk // Texts and practices: Readings in critical discourse analysis. London : Routledge, 1996. - P. 84-104. Van Dijk T. A. (2008) Introduction: Discourse and Domination / in T. A. van Dijk: Discourse and power. - N.Y.: Palgrave Macmillan, 2008. - P. 1-26.

\footnotetext{
${ }^{24}$ Dijk van Teun A., 1996, 1

${ }^{25}$ Pocheptsov, 2000

${ }^{26}$ Kutuza, 2016
} 
Denzin N.K. (2002) Interpretive Interactionism / N.K. Denzin // Applied Social Research Methods Series. - Second edition, 2002. - Vol. 16. - London: Sage. - 187 p.

Goffman E. (1974) Frame Analysis: An essay on the organization of experience / Erving Goffman. - Cambridge, Mass.: Harvard Univ. Press, 1974. -586 p.

Goffman E. (1982) The Interaction order // American Sociological Review, 1982, Vol. 48. Gumperz J. (2003) Interactional Sociolinguistic: A Personal Perspective, John Gumperz [Electronic resource]: http://www/blackwellreference.com. - 2003

Flannelly Kevin J. (2017) Religious Beliefs, Evolutionary Psychiatry, and Mental Health in America: Evolutionary Threat Assessment Systems Theory, NY, USA, Springer, Center for Psychosocial Research Massapegue, 2017.

Rotter J. B. (1990) Trust and Gullibility // The best of psychology today / Edited by Paul Chance, Ph. D. Chesapeake College and T George Harris Editor-in-Chief, Psychology Today. McGraw-Hill Publishing Company, 1990

Why an agnostic philosophy... [Elektronic resurs]: http://www.publisherweekly.com/pw/by-topic/industry-news/religion/ article/76597- Why-an-agnostic-philosophy

\section{REFERENCES}

Van Dijk T. A. (1996) Discourse, power and access /T.A. van Dijk // Texts and practices: Readings in critical discourse analysis. London : Routledge, 1996. - P. $84-104$.

Van Dijk T. A. (2008) Introduction: Discourse and Domination / in T. A. van Dijk: Discourse and power. - N.Y.: Palgrave Macmillan, 2008. - P. $1-26$

Denzin N.K. (2002) Interpretive Interactionism / N.K. Denzin // Applied Social Research Methods Series. - Second edition, 2002. - Vol. 16. - London: Sage. - 187 p.

Goffman E. (1974) Frame Analysis: An essay on the organization of experience / Erving Goffman. - Cambridge, Mass.: Harvard Univ. Press, 1974. - 586 p.

Goffman E. (1982) The Interaction order In: American Sociological Review, 1982, Vol. 48.

Gumperz J. (2003) Interactional Sociolinguistic: A Personal Perspective, John Gumperz [Electronic resource] : http://www/ blackwellreference.com. -2003

Flannelly Kevin J. (2017) Religious Beliefs, Evolutionary Psychiatry, and Mental Health in America: Evolutionary Threat Assessment Systems Theory, NY, USA, Springer, Center for Psychosocial Research Massapegue, 2017.

Research in the Social Scientific Study of Religion, V. 12., edited by Moberg David O., Piedmont Ralf L, Brill, Leiden, Boston, Köln, 2002.

Rotter J. B. (1990) Trust and Gullibility. In: The best of psychology today / Edited by Paul Chance, Ph. D. Chesapeake College and T George Harris Editor-in-Chief, Psychology Today. McGraw-Hill Publishing Company, 1990

Why an agnostic philosophy... [Elektronic resurs]: http://www.publisherweekly.com/pw/by-topic/industry-news/religion/ article/76597-Why-an-agnostic-philosophy

Adeladga, S (2002). Uspeh vo vsem. [Success in everything]. Kyiv: Svetlaya zvezda [in Russian].

Arhiv sluzhenij Vladimira Muntian i Viktorii Muntian. Krusejd - Molitva za zdorovie / 25 fevralia [Archives of services of Vladimir Muntyan and Victoria Muntyan. Krusejd - Prayer for good health / 25 february] [Elektronnyj resurs]. - Rezhym dostupu: http://vo.org.ua/tv/archive; Berlin / Krusejd/ Prayer; Krusejd / Apostol/ Prayer for good health; [in Russian]

Klymentova, O.V. (2012) Verbal'na sugestya sakral'nyh textiv (na materiali ukrains'kyh molytov) [Verbal suggestion in sacral texts (on material of the Ukrainian prayers)], Kyiv: PPNV. - 371 p. [in Ukrainian].

Klymentova, O.V. (2012) Verbal'na sugestya ta emostii (na materiali ukrains'kyh molytov) [Verbal suggestion and emotions (on material of the Ukrainian prayers)], Kyiv: Karbon LTD. - 319 p. [in Ukrainian].

Kovalevska, T.Y. (2016.) Nejrolingvistuchna identifikatsiya metaprogramnuh strategij osobustosti [Identity's metaprogram strategies' neurolinguistic identification]. In: Opera in linguistica ukrainiana, Fascicullum 23, Odessa: "PoliPrint", pp. $219-227$. [in Ukrainian].

Kompantseva, L.Ph. (2018) Lingvistychna expertyza sotsialnyh merez [Linguistic examination of social nets], Kyiv, Agrar Media Group [in Ukrainian].

Kravchenko, N.K. (2017). Diskurs i diskurs-analiz: kratkaya entsyklopedia [Discourse and Discourse-Analysis: short encyclopedia]. Kyiv: TOV "NVP Interservis" [in Russian]

Kutuza, N.V. (2016) Sugestiya i manipuljatsiya: spilni i vidminni oznaky riznovydiv (vydiv) komunikatyvnogo vplyvu [Suggestion and manipulation: common and different characteristics of varieties (types) of communicative influence] In: Zapysky z ukrainskogo movoznavstva, № 24, т.2, 178 - 189 [in Ukrainian]

Pocheptsov G.G. (2000) Informatsionnye vojny. Osnovy voenno-kommunicatnyh issledovanij [Information wars. Principles of war-communicative recearches] [Glava 2. Informatsionnaja vojna v kontekste soputstvujuschih nauk. Kommunikativnoe prostranstvo] M.: Refl-book, Kyiv: Vakler. [Elektronnyj resurs]: www.ligis.ru/librari_2/049/18.html [in Russian]

Slukhaj, N.V. (2012) Suggestiya I kommunikatsiya: lingvisticheskoe programmirovanie povedeniya cheloveka [Suggestion and communication: Linguistic Programming behaviour of man] Kyiv: IPC “Kyiv University”. - 319 p. [in Russian]

Sedov, K. F. (2011) Diskurs kak suggestiya: irratsional'noe vozdejstvie v mezlichnostnom obschenii [Discourse as suggestion: irrational influence in interpersonal communication], Moscow: Labirint, 2011. - 335 p. [in Russian] 


\begin{abstract}
Анотація
У статті аналізується вербальна специфіка сучасної місіонерської проповіді українського прозелітного дискурсу, представлена медійною активністю пасторів С. Аделаджи та В. Мунтяна. Пасторські комунікативні стратегії і тактики вербального впливу реалізовані в системі прагматичних пресупозицій та фреймів: інтерактивних, контекстуальних і фреймів взаємодії, що аналізуються в дослідженні. Окрему групу в дослідницьких матеріалах склали мовленнєві прийоми, що продукують емоційний стан довіри. В українських реаліях у місіонерських проповідях автор кваліфікує цей перлокутивний ефект як латентну форму агресії, що продукується діяльністю прозелітних організацій. Водночас у статті представлено й альтернативну позицію щодо активності деномінаційних церков, яка корелює з американськими реаліями і може розглядатися як метаперспектива для України. Але на тепер з урахуванням проблемної української безпекової аспектології є не очевидною. Результати дослідження показали, що в українських реаліях феномен емоційної довіри, який практикується як перлокутивний ефект латентного впливу, дає змогу деструктивному досвіду проникати у свідомість реципієнта і додає драматизму до індивідуальних проблем людей. Встановлено, що основні механізми та одиниці комунікативного впливу в місіонерській проповіді корелюють 3 вербальною маніпуляцією, нейролінгвістичним програмуванням та гіпнотичними техніками. Також проаналізовано специфіку мовленнєвої поведінки лідера релігійної спільноти і стратегії лідерської самопрезентації у статусно-рольовій комунікації релігійної групи.

У статті представлено різні підходи науковців до аналізу релігійного тексту, що корелює з маніпуляцією. Для експертизи прозелітних проповідей автор пропонує використовувати інструментарій інтеракціонального соціолінгвістичного методу. Окрім того, розглядаються перспективи наукової кваліфікації патогенних виявів мовлення як форми агресії у релігійному тексті.
\end{abstract}

\title{
Ключові слова
}

Місіонерська проповідь, прозелітний дискурс, мовленнєва поведінка, статусно-рольова комунікація, довіра, вербальний вплив, лінгвістична експертиза, маніпуляція, сугестія. 